Voting About God

in Early Church Councils 
This page intentionally left blank 


$$
\text { RAMSAY MACMULLEN }
$$

\section{Voting About God in Early Church Councils}

Yale University Press

New Haven \&

London 
Published with assistance from the Kingsley Trust Association Publication Fund established by the Scroll and Key Society of Yale College.

Copyright $(\subseteq 2006$ by Yale University.

All rights reserved.

This book may not be reproduced, in whole or in part, including illustrations, in any form (beyond that copying permitted by Sections 107 and 108 of the U.S. Copyright Law and except by reviewers for the public press), without written permission from the publishers.

Set in Sabon type by Keystone Typesetting, Inc.

Printed in the United States of America by Sheridan Books, Ann Arbor, Michigan.

Library of Congress Cataloging-in-Publication Data

MacMullen, Ramsay, I928-

Voting about God in early church councils / by Ramsay MacMullen. p. $\mathrm{cm}$.

Includes bibliographical references and index.

ISBN-I 3: 978-0-300-I I 596-3 (cloth : alk. paper)

ISBN-IO: 0-300-I I 596-2

I. Councils and synods. 2. Church history - Primitive and early church, ca. 30-600. 3. God-History of doctrines-Early church, ca. 30-600. I. Title.

BV7I0.M28 2006

$262^{\prime} \cdot 5 \mathrm{I} 4-\mathrm{dc} 22 \quad 2005034666$

A catalogue record for this book is available from the British Library.

The paper in this book meets the guidelines for permanence and durability of the Committee on Production Guidelines for Book Longevity of the Council on Library Resources.

1098765432 